\title{
Commentary
}

\section{Fire and water combined: Understanding the Relevance of Working Life Studies through a Concept of Practical Activity}

I Keijo Räsänen

Professor, Aalto University Business School, Finland ${ }^{1}$

DOI

10.19154/njwls.v5i3a.4833

\section{Introduction}

U

hen I presented the basic ideas of this paper at a conference, a Swedish colleague commented: 'you manage to combine water and fire.' I understood his kind comment to mean that he used water and fire as metaphors for practice and theory. The comment puzzled me for a while. Water and fire obviously destroy each other, or at least radically transform each other. Then I realized that humans have actually managed to combine water and fire in several ways. One solution is the kettle. It makes possible to use fire in a controlled way for the human purpose of boiling water. Thus, this paper can be taken as an attempt at offering a kettle-like vehicle for bringing together practicetheoretical concepts and vocational practice. My kettle is a concept of practical activity. I am trying to boil up an answer to the following question: in what senses a study of work can be practically relevant to those who are doing the work being studied?

This paper proceeds in the following way: First, I characterize the problematic of relevance in the study of working life. Secondly, I outline briefly a concept of practical activity that, as I propose, sheds light on the nature of relevance. Thirdly, I try to demonstrate the concept's use and potential by turning attention at research work and especially at its politics. The reader can thereby assess whether this way of approaching academic work is relevant to herself or himself. Fourthly, I discuss what difference this approach makes to understanding the problematic of relevance. My main claim is that the approach results in a more specific and comprehensive understanding of the senses in which working life studies can be practically relevant to the practitioner.

\section{Theories of practice and practical relevance in studies of work}

As the labels suggest, the streams of practice-based and practice-theoretical studies form a likely candidate to the provision of further resources for grasping the issue of relevance. If we want to understand what the practical relevance of research can be, we need necessarily a concept of practice. This concept should be usable in the case of both focal practice

\footnotetext{
1 E-mail: keijo.rasanen@aalto.fi.
} 
and research as practice. However, a practice theorist is not necessarily interested in being practical. As Eikeland and Nicolini (2011) aptly express, there are various ways of turning to practice, ranging from a research-as-usual modification in vocabulary or a 'change of lens' to immanent critique that questions research practice itself. It is thus a task in itself to make practice theoretical ideas practically relevant.

The difficulties of generating research that is useful to the practitioner can be made experientially recognizable by a simple test to the researcher reader. In the name of the symmetry requirement, these questions should be fair: Have you ever felt that particular studies of your own (academic) work are relevant to you? If so, what kind of studies or ways of doing research have you found relevant as to your worries and hopes as a professional academic? The same problematic is usually presented in the other way round: Have the practitioners, whose work you are researching, reported that they have some use for your research results or processes? If yes, what kind of research have you been doing then? This problematic has various labels, including the widely used expression 'theory/practice gap' or divide (Perriton \& Hodgson 2013; Stabile \& Morooka 2003). By turning the question upside down, as above, we can sensitize us to the practitioner's take on it: If you are not interested in the studies of academic work, why should others be interested in your studies of their work?

When the purpose is to consider practicality to an individual practitioner many previous accounts of research relevance are not directly to the point. They often assume that the user of knowledge is a broadly defined actor group, like workers, managers, policymakers, or citizens (see, e.g., Burawoy 2005; Eyal \& Buchholz 2010). Even discussions on so-called organic intellectuals operate usually with this kind of categories (Brook \& Darlington 2013). The demands on practicality become more stringent and concrete when we think of single individuals as the users. The approach presented here is on purpose focused on the human subject of work. At first sight this may look out to represent individualistic ontologies and thus at odds with practice-theoretical approaches. However, it is possible to take subjectivities seriously and still work within a practicetheoretical frame (Dreier 1999; Holland et al. 1998; Emirbayer \& Mische 1998). The subject's relationship to a particular practice is an empirical—and existential—question. It should not be bypassed through preassumptions. It is another matter that practitioners can and do act as collectives in many cases (see, e.g., Hasle \& Sørensen 2013). By focusing first on individuals' orientations it is possible to examine how the 'we' position is accomplished and what makes it possible and sometimes even necessary.

In working life studies, the problematic of relevance has been confronted or bypassed in many ways. I try to bring the most familiar stances up here, in order to provide a background against which it is possible to recognize and assess the specificity of our vehicle for understanding practicality. In comparison to traditional academic disciplines, this cross-disciplinary field is more tightly bound to the institutions and going concerns of working life. In the Nordic countries state-funded institutes and programs have served practical, especially policy interests, and a large number of researchers have been involved in development work at workplaces (Hvid et al. 2011; c.f. Westerholm 2007). The so-called gap between research and practice is not wide in this perspective. However, if we think of the question of who can use the studies of work as a resource in their own practice, then the picture is not so balanced.

A significant share of research is funded by instances that require relevance to particular stakeholders—or 'clients,' namely policy-makers, public administrators, union 
leaders and representatives, or the managers of private and public organizations. Topical research funded in this way is more likely to support the governance or representation of practitioners than help them in orientating to their work, in doing it, or in arranging their life at and around work. This in spite of the fact that many working life researchers feel sympathy toward employee side concerns. Policy-reactivity, as this syndrome is called, carries along the danger of becoming locked in those frames of mind that policy-makers and other powerful agents share. This will easily result in conservative or fashionable stances to methods and theoretical perspectives. Nevertheless, this kind of projects can aim to serve both practical and research purposes as analytical policy studies or as the documentation of experiences, conditions, and developments in the working life.

At the same time, a large part of the literature has been produced under the rules of traditional academic research and these rules do not necessarily favor practicality. Theoretical sophistication and methodological rigor are higher values in university contexts, and a proper distance from the 'subjects of study' is a key norm. If we consider the whole spectrum of studies in work, at least in Finland the majority of university and institute researchers repeat institutionalized practices of 'data collection and analysis,' like surveys, analyses of statistics, or case studies. The practitioners are regarded either as research objects or as sources of data, and possibly as unable or unwilling to rehearse 'theoretical thinking,' the researcher's specialty (c.f. Gardiner 2006). In these strands of research, the researcher typically takes an outsider's position and relates to the practitioners as an expert in a particular domain of knowledge (see Osborne 2004, for a typology of epistemic conduct by intellectuals). There are, however, also academic researchers who see participation in public debate as an important aspect of their practice (Kalleberg 1995).

Thus what I am trying to discuss here is unavoidably interesting only to a subset of researchers: to those who engage directly with practitioners and not only for the purpose of collecting data. These researchers are likely to position themselves within the sphere of life studied, and not above or outside of it (Eikeland \& Nicolini 2011). Researchers who engage in developmental projects at workplaces surely belong to this category (Alasoini 2006; Engeström 2015; Gustavsen 1998; Thorsrud \& Emery 1970). They are most likely concerned with the practical usability of their research processes and results among the people whose work they are developing. It, however, varies to what extent researcherdevelopers are interested in individuals and diverse subjectivities at workplaces. When the goal is to develop organizations, activities, or wider complexes, then individuals may not necessarily seem to matter much.

Another area with a keen interest in practice can be found in research done in various educational contexts, either in a vocational field or in the more general field of adult education (Seddon et al. 2010; Tynjälä et al. 1997). A scholar of teaching and learning is likely to have a direct interest in producing knowledge that is relevant to the (future) practitioner, and what may be even more important, in devising educational processes in which the practitioner learns to produce (reflexive) knowledge herself. Moreover, one cannot forget workplace ethnographers, for they have had to deal with the problematic concretely, to gain access and justify their presence in the life of others (Luff et al. 2000). They have presented sophisticated accounts of how their work has been received and what it has done (Van Maanen 2011).

One could claim that my demand for relevance to individuals is misplaced, because there is available a huge and versatile literature on how individuals can and should adapt themselves to the realities of changing working life-become successful, fit, positive, flexi- 
ble, emotionally intelligent, socially skilled, entrepreneurial, managers of themselves, able to balance work and life, or whatever is the topical need. There are therapeutic, counseling, mentoring, self-help, and 'succeed as I did it' literatures, each offering universalistic recipes or sensitive support. Specialists in human resource management teach how to deal with talents, difficult or 'different' people. These literatures are partly based on research, especially in psychology, but the human subject that appears here is not similar to the less self-sufficient and practice-bound one that appears in the practice-theoretical traditions. This concerns also a very prominent part of working life studies, namely the studies of health and 'workability.' With a few exceptions, the atomistic human subject-or body-and its condition are isolated from the actual work that the subject is doing and from the practices that mold, as well as include and exclude, subjectivities and working bodies (Ylikoski et al. 2002). Without doubt, these institutionalized lines of research aim to be practically relevant, either to an individual employee or an employer. There are only differences in how the 'who' and the 'what' are understood in the questions 'relevant to whom' and 'relevant to what.'

Finally, there are streams of research that are explicitly taking the 'standpoint' of a particular group of people (Harding 1993), or are at least motivated by a concern with their situation in the working life. As to the studies of working life, the classic choice is the standpoint of the working class. More recently it has been complemented with other groups defined by central divisions in society: women (Korvajärvi 1998; Meriläinen 2001), racially or ethnically defined groups (Kamp \& Hagedorn-Rasmussen 2004; Trux 2010), groups that are 'disabled' in particular respects (Hillborg et al. 2010), or excluded from privileges for various reasons, like the unemployed or the precariat (Fleming \& Søborg 2014; Therborn 1986). These literatures discuss explicitly the political relevance of research, but are usually more concerned with collective categories than concrete individuals. However, within this literature there are lines of engaged research that come very close to sharing what I am proposing here as a way to understand relevance.

Maybe the groups of engaged researchers, cataloged above, are especially aware of the relevance problematic: good intentions do not make relevance and the meaning of relevance is under constant negotiation between more or less powerful actors. These researcher groups may feel a need for a better understanding of what this relevance could be, and possibly for an understanding that is more tolerant and comprehensive than the often repeated, institutionalized ones.

\section{Practical activity and being practical}

We, a group of colleagues, have developed a concept of practice that potentially fulfills the expectations outlined above: usability both in the case of research work and other forms of work, and usability to individual practitioners (Räsänen \& Trux 2012). The concept has emerged in our studies of managerial work, development work, and academic work since the early 1990s. After starting from standard qualitative research with descriptive and explanatory ambitions we turned to practicing participatory and practice-based research. After a long process of trial and error we managed to create an approach that seems to work in the context of educating business professionals and professional workplace developers. Over the years we became gradually aware of the traditions of practice theory, and consequently draw increasingly on them in explicating 
our experiences and insights (e.g., Räsänen 2010). However, I leave this history aside here and only outline the concept in its current form.

A key aspect of this practice-based and practice-theoretical approach is that it suggests a revised, extended view on 'practicality.' The concept of practical activity invites practitioners and researchers to make inquiries in the tactics, politics, morals, and subjects of work.

Table 1 and Figure 1 present in a summary form the concept of practical activity. It provides a four-fold frame for articulating or describing any form of practice. The key idea is that the practitioner repeatedly encounters, and has to negotiate on, four basic issues: how to do, what to do, why to do, and who to be. Respectively, the practitioner's basic orientation to practice can vary from tactical to political, moral and personal, depending on her or his primary, situational concern. Practice theorists have also been different as to their primary stance to and assumptions about practice, as suggested in the table.

Table I The frame of practical activity (revised from Räsänen 20।4, Table I)

\begin{tabular}{llll}
\hline Issues & Orientations & Concretizations & Practice theorists \\
\hline How? & Tactical & Habits/Means & de Certeau, Goffman, Garfinkel \\
\hline What? & Political & Interests/Goals & Bourdieu, Foucault \\
\hline Why? & Moral & Justifications/Motives & Maclntyre, Taylor \\
\hline Who? & Personal & Habitus/ldentities & Holland, Dreier, Harré \\
\hline
\end{tabular}

Figure I: Practical activity and the logic of multiple perspectives.

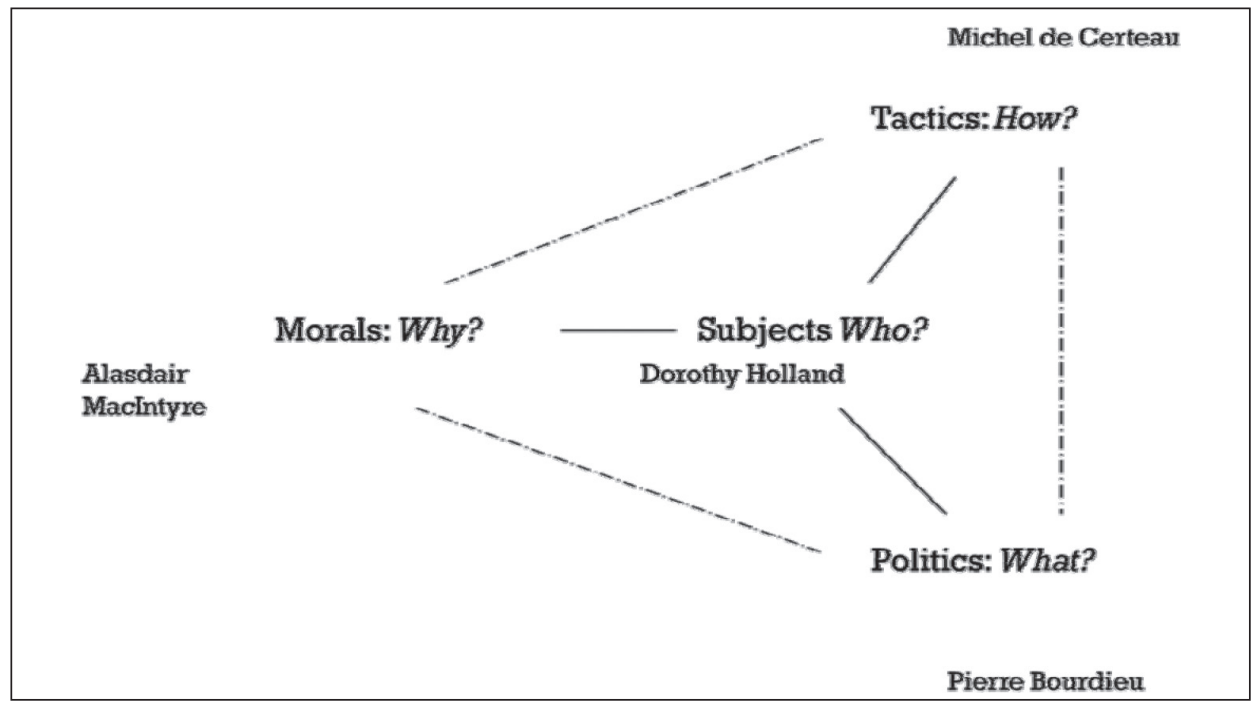

Our assumption is that all the four issues become resolved in one way or another in any practice. If the practitioner-or a collective 'we' - cannot recognize and resolve an issue, it is resolved by others, for instance by managers, or the resolution takes place by default, as scripted in work practices. We do not need to presume that practice is either 
autonomously constructed by subjects or totally given to them as a determining reality. For instance, in some situations work can serve interests of which a practitioner is hardly aware of, but in another situation a practitioner can set consciously goals on what to accomplish (produce) and achieve (in the eyes of others). In this way we can study, and even aim to contribute to, a subject's orientations and strength.

Figure 1 illustrates the logic of multiple perspectives built into this frame. The same practice looks different depending on the primary stance from which it is enacted, observed, or interpreted. From each angle you will see the three other issues and their resolutions, but they look or feel different across the angles. For example, a sociologist of work may be primarily interested in the politics of work, and even assume that the working life is basically a matter of struggles on whose interests practitioners come to serve and on what conditions. From this perspective, the tactical means and moves, any ethical discourses, and subjectivities are interpreted as the substantive contents of politics and politicking. In contrast, a moral philosopher would regard ethics as our primary stance to life and work. Both of them are right in their own way, but the point of our multidimensional framing is that practice is necessarily eclectic: the practitioner has to deal (at least) with the four issues and be able to switch orientations. It is a scholastic fallacy that all is about politics, or ethics.

While the concept of practical activity highlights four aspects of practice and their complicated relationships, we have found it sensible to assume that ordinary, usual working is tactical by nature. The practitioner, including the research worker, mainly and most of the time focuses attention on the issue of how to do, and in a half-aware, habitual mode. In other words, everyday work is about 'making do,' survival, and improvisation, and all this in and on given conditions (c.f. Certeau 1984). This working hypothesis has worked well when we have asked academics to make inquiries in their own work and reflect on their doings (Räsänen \& Korpiaho 2011). Dropping the rhetorics of heroism and rationalism is conducive to honest and open communication. However, the concept allows also for the possibility that in specific circumstances particular practitioners can be stronger subjects and consciously deal with political, moral, or identity issues.

Being 'practical' gains extended meaning through the concept of practical activity. It is not only about being tactically, or 'technically' skilled and inventive. It goes even further than the political expression 'let's be pragmatic' suggests. This saying usually implies that one should not 'rock the boat' and work against the dominant ideology or doxa in Bourdieu's (1990) terms. In addition to these tactical and political aspects of practicality, the concept asks after the moral motives for doing something and in a certain way, and after what a practice does to the practitioner. Moreover, the frame directs attention at the issues to be solved and not at their particular resolutions. It is sometimes practical to take up the questions that particular, assumed, or required answers hide. Rocking the boat may in some cases be not only fun but a wise response to the political issue.

An activity is truly practical when it is tactically skillful, oriented consciously to political goals, morally motivated and justified, and supportive and expressive of the practitioner's identity. This broader understanding of practicality is not in vogue in these times, but it has lived long. The concept of practical activity is in fact a reinterpretation and reinstrumentalization of the Aristotelian idea of praxis (Räsänen 2009). We are hardly ever practical in this strict sense of praxis, for we cannot usually resolve all the four basic issues and in a coherent way. It may, nevertheless, be more practical to encounter and try to deal with the issues than ignore or hide them. In this respect

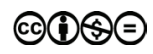


practitioners are dependent on circumstances. Practical action is impossible in insane or suppressive conditions. Some conditions make subjects too weak to learn and choose means, set goals, appreciate and prioritize various good things and thereby form, sustain and express a personal identity-and to mobilize collective action.

Practical activity is a functional concept and not a formal one (Greeno 2012). We have developed it to enable the articulation and description of particular forms of work in educational, developmental, and participatory research contexts. For instance, in the course on academic work participants are asked to articulate their goals, and thereby the goals become an object of reflection and possible revision (Räsänen 2009). Moreover, participants make joint inquiries in the specter of possible goals and in the influences that bear on individuals when they unknowingly adopt or consciously choose certain goals. The aim is to understand better the politics of academic work and entertain the possibility that one can act politically, and not only tactically. This is one step in a peerlearning experience that then proceeds to inquiries in the possibilities of moral action, professional identity, and collective praxis.

The meaning of a functional concept becomes clear only in its use. For space reasons I cannot describe our practice here, but I can give an example of the difference that this kind thinking makes when one is trying to understand a form of research practice and its relevance. While the strength of the concept of practical activity lies in taking into account all the four issues of practical activity, I focus here on the politics of practice in order to make the concept's import examinable. What follows is an attempt at explicating the uses of the concept by discussing a form of work that is familiar to most readers of this journal, namely research.

\section{Research work as practical activity: the political issue of goals}

In any study the researcher has to resolve the issue of what to accomplish and achieve in the study. Articulating the goals of research work may in itself be a difficult task, but it is even more demanding to be critically reflexive with respect to one's goals. Reflexivity usually requires extra resources. Otherwise one easily keeps repeating old patterns of reasoning and comes to reproduce the doxa of one's own field. New cultural resources may also be of help already when the academic is trying to identify and name the implicit and explicit goals that she or he pursues in single studies.

The goals of research work can be classified in numerous ways. I have found Kalleberg's (1995) characterization of research questions and designs in sociology very useful. He names three types of research question and task (Table 2). His purpose is to argue that Action Research also belongs to the legitimate forms of sociology. However, his typology covers a wide range of research styles typical at least in organization and management studies, and I would argue here, in the study of work. After minor modifications and additions (Räsänen \& Mäntylä 2001), the classification has worked very well in our local context, with new researchers and more experienced colleagues. I first outline the set of potential goals, and then propose senses in which we are talking about research politics here. The question is what researchers do to their research objects.

The most familiar and widespread understanding is that 'scientific' research is constative by nature. The possible goals are to conceptualize, describe, and explain something. The critical variant is also familiar to the researchers of work. In fact its existence 
Table II Types of research questions and task (modified from Kalleberg 1995, see Räsänen \& Mäntylä 200I)

\begin{tabular}{ll}
\hline Constative & \\
What is it? & Conceptualization \\
How is it? & Description \\
Why is it (like that)? & Explanation \\
\hline Critical & \\
How good is it? & Ideology/cultural/ immanent critique \\
On what basis is its goodness evaluated? & \\
\hline Constructive & Identification of alternatives \\
How could it be? & Evaluation of alternatives \\
How should it be? & Intervention \\
How can it be changed? & \\
Is the change effort worth its (human and other) costs? & Evaluation of interventions \\
\hline
\end{tabular}

structures the field significantly. While economists explain by economic efficiency or economizing, many sociologists are prone to question these explanations by reference to power and dominance, that is, to the ideological nature of economics. What may look good or justified from an efficiency perspective, may look problematic from the power perspective. The critique can aim to reveal a particular value basis or political interest behind the claims on goodness by others. Seldom do researchers concentrate on explicating their own value basis. A famous example of critical research from the recent decennia is so-called deconstruction, the task of showing that the normative content of a text or practice is only a possible (biased) alternative and not a necessary one.

The third, constructive type, originally presented as Action Research in Kalleberg's discussion, contains various forms of participatory research, in which the purpose is not only to understand a world but to change or improve it - or to sustain something valuable (like self-determination). Most of those who study work either practice this kind of research or at least know of colleagues that are doing intervention studies of some kind. However, the scientific status of constructive research has always been contested among academics, even more fiercely than that of critical research.

In what senses are we talking about politics here? In each study the researcher unavoidably takes a stance to the issue of what to accomplish and achieve. Kalleberg's classification is one interpretation of the potential accomplishments, and as such a political statement in itself. He takes part in debates on proper goals in sociological research, and simultaneously, on whose interests studies should serve. The different fractions of sociologists have their own ways of expressing research goals and orders of priority among the acceptable goals. Similar struggles are going on in every field of research. A school of thought can make subtle distinctions between different interpretations of the goals, and define thereby who are 'we' and who are 'others' in academia. A recent example is the fierce debate in the United States around the return to the 'gold standard,' namely experimental, quantitative research, advanced by the Bush administration and critiqued by the representatives of qualitative research. Another example can be found within 
qualitative studies: Is the tasks first to describe and then explain something puzzling in the findings, or is a deep description already an explanation? A third example of debate concerns the value of so-called 'effect studies' that are claimed to result in 'evidencebased practice.' A fourth example is whether product-like deliverables from a development project deserve to be taken as research results.

Think about the training and guidance that you received, or are receiving as a young scholar. Either intentionally or by default and as continuation of a tradition senior academics prefer some research goals and omit other goals. In some units, new academics are advised or even expected to do constative research (and this understood in a specific way), while some other centers of research and doctoral education may favor or at least accept critical or constructive approaches. The young, new researcher may not first even understand what the key terms like 'explain' mean in practice, but gradually and after research experience the terminology starts to make sense. Thereby the new researcher joins in a local or international tradition. Of course, this is only an overly generalized account of what is going on in doctoral education, and there is nothing deterministic in these socialization processes. New researchers may in many cases question the wisdom of their advisors and search after alternative views on the goals.

In the end, the actual goals of a study or set of studies are a matter of multipleimplicit or explicit—negotiations. A doctoral student may have her or his own ideas of proper outcomes, but thesis advisors and examiners have their say on the matter, and accept or reject the ideas. Moreover, people in the small worlds studied may also more easily accept particular explicit goals and outcomes than some other ones. Some forms of research are more institutionalized, and thus more easily justifiable, than some other ambitions. A project of 'feminist, critical, emancipatory action research' is more likely to meet resistance from gatekeepers than a less dangerous, more controllable survey project with questionnaires and predetermined objectives.

What difference does it make to consider goal-setting a generic issue in practical activity? This way of thinking sensitizes us to the multiple influences on our goal-setting. It invites a critically reflective attitude toward our own practice and any suggestions or teachings on what to aim at. It may result in the recognition of various alternatives to the one that we have already been introduced to. Overall, the research practitioner can become more aware of politics in research. Moreover, this sensitizing can be aided by all the cultural resources that practice-theoretical perspectives can bring to the matter.

While traditional teaching in the philosophy of science and in research methods has tended to represent the issue of goals as a purely intellectual question (propagating 'proper research'), practice theories lead one to examine the bodily, temporal, and both materially and socially relational aspects of research education and work. These extra resources may make the unspeakable and unrecognized a matter of conscious inquiries. The differences made by this move may not be big in substantive terms, as the methodical and epistemological problems remain similar as before, but one's personal orientation toward them may go through a significant change. Normative research ideals may lose some of their mythical, authoritative power and an ordinary academic may recognize their nature as a human and social affair. In order to be a conscious, political actor with autonomously set goals, the researcher has to become aware of the field of influences and of her or his possibilities under them.

Finally, the frame of practical activity provides a heuristic idea on how the political issue can be resolved in practice. According to the logic of multiple perspectives, the 
answer to the question what to accomplish and achieve can be developed by dealing with the three other questions: Who do I want to be as a researcher, why am I doing research work, and how do I want to do research? The substance of politics is in the three other dimensions of practice.

\section{Relevance in four respects}

After the example from research politics it is now possible to ask again 'what kind of research is relevant to the academic practitioner.' The answer is that such studies of academic work are relevant that help in resolving the issue of what to do. This kind of studies can concern various topics and approach academic work from various perspectives, but they make academic research politics more understandable, provide alternative resolutions to the issue, or help the practitioner in the articulation of her or his own practice, as well as, of hopes and worries that have been hard to express.

For instance, in some research circles scholars are dissatisfied with the standard styles of academic writing, and worried for the necessity to fit one's style to the demands of the 'top journals.' The studies on academic literacy and diverse genres of academic writing may open up new possibilities as to the goals of writing, give good arguments with which to defend one's goals, and aid in assessing the consequences of choosing this or that genre (see, e.g., Bazerman 2008). This literature directs attention at the nature of the text to be written, its genre, the accomplishment of which is a substantive goal internal to research effort and not only at the external merit achieved by writing the text.

The same goes for the three other issues of how, why, and who. Relevant research helps in resolving any of them, that is, it improves awareness of the tactical, moral, or personal aspect of research practice. Altogether, relevant research supports the researcher as a more or less strong subject in practice.

This perspective to relevance both broadens its meaning and makes the expectation more specific. At least, the only form of relevant research is not to give pieces of advice on the 'how to do' question. If this was the case, the only category of relevant study would concern research practices and less well-documented, informal tactics that academics use to survive, 'make do,' or succeed in academia. While this is very relevant in itself, academic practitioners have to deal with the other issues, too. As elaborated earlier, studies that help in dealing with academic politics, and with such suggestions as 'be pragmatic' or 'do not rock the boat,' can be relevant, too.

Then there is the potentially very powerful and fruitful issue of academic morals. Although currently less discussed and studied than politics, the morals of academic work is an acute concern to many academics due to the ongoing changes in universities. This issue is, unfortunately, treated often merely in terms of ethical codes and misconduct, of how one should not behave. It has also another, more generative side: what are the internal and external 'goods' that make academic work worth doing (MacIntyre 1985), may function as moral motives for the academic, and may help her or him to keep a track and persevere under hostile control and inhuman expectations (c.f. Järvensivu 2006, Ch. 5, on moral contracts in working life). And, there are studies that support professional identity projects in academia, and in particular, recognize and appreciate differences in the social backgrounds and orientations of academics. Visible examples are the wide literatures on the experiences, doings, fates, and alternative stances of female 
academics and academics with a working class background (c.f. Mulinari \& Selberg 2013, on intersectionality).

The four practical issues are interdependent, and therefore relevant studies can also concern these interdependencies, as well as, previous attempts to construct a form of praxis with relatively coherent resolutions to all the four issues. I would consider especially important studies that aid in breaking the focus solely either on working practices (or 'methods') or on politics. These problematics may see and feel quite different, if they are approached from a moral perspective or from the perspective of diverse subjectivities. As there are already accounts of academic practice that remind a form of praxis or claim to be such, it is possible to generate points of comparison for a local practice and its circumstances (Räsänen 2014). To mention one example, Pierre Bourdieu's attempt to create a 'collective intellectual' has been documented in detail by his former collaborators (e.g., Lenoir 2006).

The frame also suggests ideas on how to describe research practice in its diverse forms. One can focus on researchers' working practices and habits, their understanding of the goals of work and the nature of their accomplished 'products' or performances, the internal and external goods valued in the practice, and to researcher identities, agency (i.e., the sources of strength in practices), and forms of thought and affect. For instance, the types of research design named by Kalleberg should look and feel different in these respects. Remembering that ordinary work, including research work, is by nature tactical is important in any effort of this kind. Otherwise one regards us academics wiser-or more self-aware-than we are. Mostly, I assume, we rehearse inherited practices and can only partly account for our doings. Van Maanen (2011) gives an example of what focusing on working practices can result in.

Abbott $(1993,206)$ ended his review of the sociology of work and occupations by saying that 'most of the really exciting work ... has a consistently politicized tone, while most of the apolitical work is intellectually sterile.' Could it be that there are also other exciting 'tones,' namely the tactical, moral, and personal one? I believe that research can be interesting in many ways (see Boyer 2010, on multiattentionality), when the researcher dares to go beyond the position of a neutral, 'theoretical' spectator and speak to the issues of human practice (c.f. Rees 2011). In Markova's (2012) terms, the researcher is then willing to appreciate the 'common sense forms of objectification' and does not pretend to be above them. Nevertheless, we should not forget Bourdieu's (2003) demand on an epistemic break with common sense. Repeating doxa can be taken as relevant by some instances, but is it relevant in the sense of praxis? Boltanski and Thévenot add that practitioners are themselves capable of critique, and not only critical sociologists (e.g., Thévenot 2011).

If you now think that the concept of practical activity opens up a more specific and comprehensive understanding of what kind of issues academic practitioners need to resolve in their practice, then you might consider using the idea in specifying the relevances that your research can generate in relation to other forms of work. A few notes on development work follow.

\section{Relevances in development work}

Researchers engaged in development work at workplaces unavoidably need to argue for the relevance of their work. They have had to develop sophisticated and credible views on the relevance problematic. A few notes on what the concept of practical activity can 
bring to these situations should make the idea more concrete and move the focus away from mere academic work.

We have previously suggested that the concept aids in articulating, describing, and comparing different forms of development work (Räsänen 2007, 2012). We have called these forms of practice in English 'developmental approaches.' The Finnish term kehittämisote refers more concretely (and corporeally) to developers' grasp and grip of development practice, and makes it possible to remember that developers are only partially aware of their practice-or can lose their grip altogether under contradictory pressures. Nevertheless, their practice can be seen to contain more or less coherent and sustainable resolutions to the tactical, political, moral, and personal issues: how to develop, what to develop, why develop it and in this way, and who develops. As the resolutions are different across developmental approaches, the concept can contribute to gaining a better self-awareness among developers of their specific and different forms of practice.

For instance, most developmental approaches favor in principle participation, but there may be significant differences across them in the actual procedures of participation (how), development goals in terms of participation (what to accomplish in projects), justifications of participation and motives for advancing it (why), and assumptions about the subjects who are capable of, and included in or excluded from, participation (see Beirne 2008, on idealism and relevance in efforts to increase participation).

The crucial question is whose conception of relevance is taken into account in planning and negotiating on development projects. When the counter-side, and possible funder of the project, is the management of a private company or public organization, it is likely that their views on relevance dominate the discussion. In the ideology of managerialism, it is the manager who can best resolve the issues of why, what, and who (Räsänen \& Trux 2012). The developer and the employee are supposed to focus on the question of how to realize goals defined by the manager: only new tools and improvements in performance are (usually) relevant, or merely proving managerial competence by following a trend.

However, other participants may hope for other outcomes from the effort. For the researcher-developer it may be very crucial, for instance, to define the object of development and expected changes in it in a certain way-be it business processes, activity systems, quality of working life, or forms of interaction and communication. As to the justifications and moral motives of developmental efforts, the developer may have originally entered this line of work in order to 'improve the world' in some other respect than merely increasing profits. The developer's hopes meet more or less well what the employees expect from the never-ending waves of change. Finally, the developer may have expectations as to the combination of people involved in the project, and beyond that, as to the personal development of the participants and their position in the work organization. As professional practice, development work is demanding and consuming due to the kind of tensions between different resolutions to the basic issues and between different logics of resolving them. Moral motives and virtues are tested by tactical, political, and human complications.

The concept of practical activity aims at making the tensions of practice discussable. It suggests that it is impractical to focus on resolving only the tactical issue of how, while the other basic issues are left to resolution by default, or by managerial ideology and its changing fashions. The researcher-developer should be in a better position to defend her or his moral-political vision, if he or she is able to recognize and express it, and is capable of doing the same to the visions of other stakeholders. The four questions form an agenda 
for dialogues of this kind. In the opposite case, when goals and motives for developmental work, as well as participant's vocational identities are unaddressed, we can witness (countless) projects that bear no fruit. Paying attention to the orientations of individuals involved in this kind of dialogues or negotiations, or are bearing their consequences, does not solve the major problems of developmental work. Nevertheless, 'concrete others' and their orientations, to use phenomenological expressions (Kögler 2006), may deserve some attention in developmental practice and in the study of developmental work.

\section{Conclusion}

My main point is that we need a well-rounded concept of practice if we want to understand the possibilities of and difficulties in making research that practitioners find relevant. I have suggested that the concept of practical activity provides a way of approaching this problematic, and illustrated the uses of the concept with the issue of goal-setting in academic work and with brief notes on development work. What would this approach mean and give when studying other forms of work?

In the frame of practical activity, practitioners have to encounter and deal with the four basic issues in any form of work (Räsänen \& Trux 2012). Thus the study of a certain line of work can be relevant with respect to any of them, in principle. We can speak of tactical, political, moral, and personal relevance. Relevance means that the practitioner can use research in defending or revising her or his orientations to work (see Buch \& Andersen 2013, on the importance of orientation).

There is no way of jumping over the practitioners' ('emic') orientations to their own work. Researchers cannot a priori know what the practitioner takes as relevant, and therefore the approach relies on an intimate knowledge of her or his work. The approach works best when it is used in a dialogical way. This means that the current practice and its dilemmas are articulated collaboratively between the practitioner and the researcher. When used in this way, the concept of practical activity provides a potential bridge between researcher and practitioner knowledge. The four issues provide them with meeting points.

The managerial logic of governance is a general hindrance in many workplaces for acting upon the extended idea of practice. The ideology of managerialism presumes that the managers resolve moral, political, and identity issues-if they exist at all in marketdriven workplaces, and the employee has something to say only on the question of how to realize goals set and monitored by the managers. Thus, it is no wonder that our approach has emerged to its current form in the context of academic work. In a Finnish university it was possible, still some time ago, to rehearse collegial discussions and negotiations on the basic issues of academic work. Now this possibility is fading away swiftly. Taking a moral stance to academic work has even become one reason for excluding an academic from a career in this university. It remains to be seen whether there are or will appear other workplaces that support professional or vocational control of work. If practice is diminished to technocratic routines or hectic improvisation, practitioners may not anymore be capable of appreciating practical relevances that are missing from their spheres of work.

A lot is still to be done in making practice-based studies and practice-theoretical traditions practically relevant. This effort is worthwhile, because these traditions speak about practice and take it seriously, at least in principle (Kemmis 2011). In the field of 
working life studies, we can learn especially from researcher-developers who already have encountered the need to be practical and draw on traditions of participatory research, well-known in the Nordic countries. They can offer advanced views and concrete practices by which to identify and name the nature of practicality in different situations. The representatives of more distanced and neutralized version of academic research, on the other hand, may be able to share experiences from participation in public debate and from the ways of relating research agendas to policies and funding systems.

Hopefully our tiny kettle provides a conceptual vehicle for a few conversations across research traditions and with various forms of practice. By choosing a direct and polemical style for this account, or cooking recipe, I aimed at provoking discussion on relevance and not at offending fellow researchers. Anyway, we need both water and fire.

\section{References}

Abbott, A. (1993) The Sociology of Work and Occupations. Annual Review of Sociology 19, 187-209.

Alasoini, T. (2006) In Search of Generative Results: A New Generation of Programmes to Develop Work Organization. Economic and Industrial Democracy 27: 1, 9-37.

Bazerman, C. (2008) Genre and Cognitive Development. In: C. Bazerman, A. Bonini, \& D. Figueiredo (Eds.), Genre in a Changing World. Fort Collins, CO: The WAC Clearinghouse and Parlor Press, 279-294.

Beirne, M. (2008) Idealisms and the Applied Relevance of Research on Employee Participation. Work, Employment and Society 22: 4, 675-693.

Bourdieu, P. (1990) The Logic of Practice. Cambridge: Polity Press.

Bourdieu, P. (2003) Participant Objectivation. The Journal of the Royal Anthropological Institute 9: 2, 281-294.

Boyer, D. (2010) On the Ethics and Practice of Contemporary Social Theory: From Crisis Talk to Multiattentional Method. Dialectical Anthropology 34, 305-324.

Brook, P. \& Darlington, R. (2013) Partisan, Scholarly and Active: Arguments for an Organic Public Sociology of Work. Work, Employment and Society 27: 2, 232-243.

Buch, A. \& Andersen, V. (2013) (De)stabilizing Self-Identities in Professional Work. Nordic Journal of Working Life Studies 3: 3, 155-173.

Burawoy, M. (2005) For Public Sociology. American Sociological Review 70, 4-28.

Certeau, M. de (1984) The Practice of Everyday Life. Berkeley, CA: The University of California Press.

Dreier, O. (1999) Personal Trajectories of Participation Across Contexts of Social Practice. Outlines 1: 1, 3-52.

Eikeland, O. \& Nicolini, D. (2011) Introduction. Turning Practically: Broadening the Horizon. Journal of Organizational Change Management 24, 164-174.

Emirbayer, M. \& Mische, A. (1998) What Is Agency? American Journal of Sociology 103: 4, 962-1023.

Engeström, Y. (2015) Learning by Expanding: An Activity-Theoretical Approach to Developmental Research (2nd ed.). Cambridge: Cambridge University Press. ( ${ }^{\text {st }}$ ed. 1987).

Eyal, G. \& Buchholz, L. (2010) From the Sociology of Intellectuals to the Sociology of Interventions. American Sociological Review 36, 117-137.

Fleming, D. \& Søborg, H. (2014) The Debate on Globalization and International Revitalization of Labor. A Critical Review. Nordic Journal of Working Life Studies 4: 1, 53-68.

Gardiner, M. E. (2006) Everyday Knowledge. Theory, Culture \& Society 23: 2-3, 205-207. 
Greeno, J. (2012) Concepts in Activities and Discourses. Mind, Culture, and Activity 19: 3, 310-313.

Gustavsen, B. (1998) From Experiments to Network Building: Trends in the Use of Research for Reconstructing Working Life. Human Relations 51: 3, 431-448.

Harding. S. (1993) Rethinking Standpoint Epistemology: What Is 'Strong Objectivity'? In: L. Allcoff \& E. Potter (Eds.), Feminist Epistemologies. London: Routledge, 49-82.

Hasle, P. \& Sørensen O. H. (2013) Employees as Individually and Collectively Acting Subjects-Key Contributions from Nordic Working Life Research. Nordic Journal of Working Life Studies 3: 3, 9-30.

Hillborg, H., Svensson, T. \& Danermark, B. (2010) Towards a Working Life? Experiences in a Rehabilitation Process for People with Psychiatric Disabilities. Scandinavian Journal of Occupational Therapy 17: 2, 149-161.

Holland, D., Lachiotte, W. Jr., Skinner, D., \& Cain, C. (1998) Identity and Agency in Cultural Worlds. Cambridge, MA: Harvard University Press.

Hvid, H., Bergholm, T., Gönas, 1., Juul, I., Kamp, A., Karlsson, J., Kasvio, A., Klemsdals, L., Salomon, R. \& Skorstad, E. (2011) Nordic Working Life Research-Continuity and Renewal. Nordic Journal of Working Life Studies 1: 1, 3-21.

Järvensivu, A. (2006) Oppiminen työnä ja työpaikkapelinä. Tampere: University of Tampere (Ph.D. dissertation).

Kalleberg, R. (1995) Action Research as Science and Profession in the Discipline of Sociology. Unpublished manuscript for S. Toulmin and B. Gustavsen (Eds.), Beyond Theory: Changing Organizations through Participatory Action Research. Amsterdam: John Benjamins.

Kamp, A. \& Hagedorn-Rasmussen, P. (2004) Diversity Management in a Danish Context: Towards a Multicultural or Segregated Working Life? Economic and Industrial Democracy 25: 4, 525-554.

Kemmis, S. (2011) What Is Professional Practice? Recognising and Respecting Diversity in Understandings of Practice. In: C. Kanes (Ed.), Elaborating Professionalism, Dordrecht: Springer, 139-165.

Korvajärvi, P. (1998) Reproducing Gendered Hierarchies in Everyday Work: Contradictions in an Employment Office. Gender, Work and Organization 5: 1, 19-30.

Kögler, H.-H. (2006) Hermeneutics, Phenomenology and Philosophical Anthropology. In: G. Delanty (Ed.), Contemporary European Social Theory, New York: Routledge, Ch. 15.

Lenoir, R. (2006) Scientific Habitus: Pierre Bourdieu and the Collective Intellectual. Theory, Culture \& Society 23: 6, 25-43.

Luff, P., Hindmarsh, J. \& Heath, C. (2000) Workplace Studies: Recovering Work Practice and Informing Systems Design. Cambridge: Cambridge University Press.

Markova, I. (2012) Objectification in Common Sense Thinking. Mind, Culture, and Activity 19: 3, 207-221.

MacIntyre, A. (1985) After Virtue. A Study in Moral Theory (2 ${ }^{\text {nd }}$ ed.). London: Duckworth.

Meriläinen, S. (2001) Changing Gendered Practices: A PAR Project within an Academic Work Community. Acta Universitatis oeconomicae Helsingiensis A-192. Helsinki: Helsinki School of Economics.

Mulinari, P. \& Selberg, R. (2013) Intersectional Directions in Working Life Research: A Proposal. Nordic Journal of Working Life Studies 3: 3, 81-98.

Osborne, T. (2004) On mediators: intellectuals and the ideas trade in the knowledge society. Economy and Society 33: 4, 430-447.

Perriton, L. \& Hodgson, V. (2013) Positioning Theory and Practice Question(s) Within the Field of Management Learning. Management Learning 44: 2, 144-160.

Rees, T. (2011) As if "Theory" Is the Only Form of Thinking, and "Social Theory" the Only Form of Critique: Thoughts on an Anthropology BST (Beyond Society and Theory). Dialectical Anthropology 35, 341-365. 
Räsänen, K. (2007) Kehittämisotteet: kehittämistyö 'käytännöllisenä toimintana’ [Approaches to Developmental Work: Developmental Work as 'Practical Activity']. In: E. Ramstad \& T. Alasoini (Eds.), Työelämän tutkimusavusteinen kehittäminen Suomessa. TYKES Reports 53, Helsinki: Ministry of Labour, 40-66.

Räsänen, K. (2009) Understanding Academic Work as Practical Activity—and Preparing (business-school) Academics for Praxis? International Journal for Academic Development 14, 185-195.

Räsänen, K. (2010) On the Moral of an Emerging Academic Praxis: Accounting for a Conference Experience. In C. Steyaert \& B. Van Looy (Eds.), Relational Practices, Participative Organizing. Bingley: Emerald, 155-176.

Räsänen, K. (2012) 'That's Dangerous'. Autonomous Development Work as a Source of Renewal in Academia. In: B. Stensaker, J. Välimaa \& C. S. Sarrico (Eds.), Managing Reform in Universities. Basingstoke: Palgrave, 179-197.

Räsänen, K. (2014) Academic Capitalism and Practical Activity-Extending the Research Program. In: B. Cantwell \& I. Kauppinen (Eds.), Academic Capitalism in the Age of Globalization. Baltimore: John Hopkins University Press, 94-112.

Räsänen, K. \& Korpiaho, K. (2011) Supporting Doctoral Students in their Professional Identity Projects. Studies in Continuing Education 33, 19-31.

Räsänen, K. \& Mäntylä, H. (2001) Preserving Academic Diversity: Promises and Uncertainties of PAR as a Survival Strategy. Organization 8, 301-320.

Räsänen, K. \& Trux, M.-L. (2012) Työkirja-ammattilaisen paluu [Work Book-The Return of the Professional]. Helsinki: Kansanvalistusseura.

Seddon, T., Henriksson, L. \& Niemeyer, B. (2010) Learning and Work and the Politics of Working Life: Global Transformations and Collective Identities in Teaching, Nursing and Social Work. London: Routledge.

Stabile, C. A. \& Morooka, J. (2003) 'Between Two Evils, I Refuse To Choose the Lesser'. Cultural Studies 17: 3-4, 326-348.

Therborn, G. (1986) Why Some Peoples Are more Unemployed than Others. London: Verso.

Thévenot, L. (2011) Power and Oppression from the Perspective of the Sociology of Engagements: A Comparison with Bourdieu's and Dewey's Critical Approaches to Practical Activities. Irish Journal of Sociology 19: 1, 35-67.

Thorsrud, E. \& Emery, F. E. (1970) Industrial Democracy in Norway. Industrial Relations 9: 2, 187-196.

Trux, M.-L. (2010) No Zoo: Ethnic Civility and Its Cultural Regulation Among the Staff of a Finnish High-Tech Company. Acta Universitatis Oeconomicae Helsingiensis A-359, Helsinki: Helsinki School of Economics.

Tynjälä, P., Nuutinen, A., Eteläpelto, A., Kirjonen, J., \& Remes, P. (1997) The Acquisition of Professional Expertise-A Challenge for Educational Research. Scandinavian Journal of Educational Research 41: 3-4, 475-494.

Van Maanen, J. (2011) Ethnography as Work: Some Rules of Engagement. Journal of Management Studies 48: 1, 218-234.

Van Manen, M. (1977) Linking Ways of Knowing with Ways of Being Practical. Curriculum Inquiry 6: 3, 205-228.

Westerholm, P. (2007) Closing the Swedish National Institute for Working Life. Occupational and Environmental Medicine 64, 787-788.

Ylikoski, M., Launis, K., Lehto, A.-M., Mäkitalo, J., \& Räsänen, K. (2002) Blind Spots in Work Ability Research and Knowledge. In: P. Peltomäki, T. Hussi, H. Julin, K. Launis, J. Liira, \& K. Räsänen (Eds.), Maintenance of Work Ability Research and Assessment: Summaries. Helsinki: Ministry of Social Affairs and Health, Finnish Institute of Occupational Health \& Social Insurance Institution. Report 7. 